\title{
sciendo
}

\section{The Emigration and Influence Factors in Romania}

\author{
Andreea-Oana ENACHE \\ The Institute of National Economy \\ enacheoanaa@yahoo.com
}

\begin{abstract}
The economic and social transition affected the population and the demographic phenomena in all the ex-communist countries. Immigration can be considered as a potential solution to the problem of population aging. But here too, it must be born in mind that immigrants may not properly adapt to the new labor market they have entered, if they come from very different cultures. Almost all the countries that have migrants, offer residence permits only to those who bring highly qualified workforce, while the legal possibilities of immigration of the unskilled workers are diminishing. Therefore, the demographic perspectives are not the most optimistic. The forecasts developed by specialists reveal dramatic future developments for the population of Romania. The factors that can cause a person to migrate are of several types. In this study it will be shown that migration is the result of several individual actions of analysis, people evaluating both the benefits and the risks involved by a possible migration.
\end{abstract}

Keywords: migration, definitive emigrants, definitive immigrants, earning, registered unemployed.

\section{Introduction}

The name of migration comes from the Latin term migratio and has different meanings. In time, migration meant mass movement of tribes or populations from one territory to another, determined by economic, social, political or natural factors or mass movement of animations from one region to another, for breeding, searching for food etc.

Currently, the term migration refers to move or change the place of life (living and working) determined by social, political, economic or natural factors. Migration always involves changing the domicile and, most of the times, leaving a place to move to another better, more constructive or productive in terms of human quality of life.

Migration has existed since the beginning of mankind. The phenomenon never ceased, but it took different forms over time, recording slight changes. Most of the time, migration meant to move from one country to another, but internal migration is also possible. Migration can be individual, in families or in large groups (in mass).

According to the 2010 report of the International Organization for Migration, the number of migrants was estimated to reach 220 million in 2013. If this number will keep the pace of growth, it will reach 405 million in 2050.

Although modern migration can be caused by wars (for example, emigration from Iraq and Bosnia to the United States of America and the United Kingdom), political conflicts (for example, emigration from Zimbabwe to the UK) or natural disasters (e.g.: emigration from Montserrat to the UK as a result of the volcanic eruption on the island), most often based on economic considerations. Specifically, there are large discrepancies in people's incomes for similar work in different parts of the month. Also, there are jobs in very well developed countries with skills shortage among its citizens. 
Unfortunately, part of modern migration happened even if the migrant becomes an illegal resident in the country of destination and creates a major disadvantage in the labor market.

In the case of internal migration, the rural-urban migration is distinguished by magnitude. This migration occurs especially in the states in the industrialization phase. On the other hand, in developed countries, there is also an inverse flow: from urban to rural.

The paper aims to analyze migration as the result of several individual analysis actions, by verifying the significance of individual specific effects ( $\beta i$ ) through the Hausman test and the fixed effects through redundancy tests.

\section{Literature review}

Migration is the movement of an individual or a group of individuals from one territory to another, across a political or administrative border, aiming to be established temporarily or permanently in a place, namely in the country of destination (Roman, M., and Voicu, C., 2010).

Newell Colin (1988, p. 82) considered migration to be one of the most important components of population change.

According to Zelinsky W. (1966, pp. 43-44), migration is a cultural phenomenon and a dynamic element, representing more than fertility and mortality in the population. Migration is a general design of the society in which economic, social, demographic factors are included. According to Trewartha G. T. (1969, p. 135), migration is an indicator of the racial, linguistic and nationalist mixing of the global population. He emphasized distance, human will and a permanent change of domicile. Trewartha stated that the term "migration" has several meanings, most commonly involving moving over a certain distance, the result of which is the change of permanent residence.

Another interesting theory regarding the determination or motivation of people to migrate is outlined by Abraham Maslow in the form of five basic human needs that trigger most of his behaviors. Abraham Maslow was an American humanist psychologist, and the main contribution in psychology was in the problem of hierarchizing human needs, according to physiological needs (food, water, heat, environment conducive to life), safety needs (security, stability, health, lack of dangers), social needs for affiliation and love (belonging to a group, to a family), needs for self-esteem (self-esteem, recognition of others, respect for others), needs for self-fulfillment (autonomy, freedom, competence).

In addition to Maslow's theory, in the 1880s, Ernst Georg Ravenstein, an EnglishGerman geographer, built another theory to describe the migration of people. In addition to the migration theory, Ravenstein estimated at the end of the 19th century, the population of the world at that time. He also estimates a maximum that could be sustained by the Earth's resources, in 2072. His theory of migration developed in the 1880 s is still at the base of modern migration theory. The theory takes into account the implications of distances and different types of migrants, but also the fact that women are more likely to migrate within the country where they were born than men, while they are more likely to leave their homeland.

Therefore, migration represents the movement of the labor force, which records increased flows and most often changes in meaning and intensity. Considered on a historical scale, the problem of this phenomenon, whether we speak of internal migration or international migration, represents for many states an additional concern. Labor migration is a complex, multidimensional process that generates challenges, costs and benefits, which 
must be carefully managed by states.

\section{Methodology}

The data used in the calculation are taken from the National Institute of Statistics (www.insse.ro) and refer to:

- Definitive immigrants by sex, macroregions, development regions and arrival counties, number of persons, 1991-2017, National Institute of Statistics, TempoOnline, POP310A table - Definitive emigrants by sex, macroregions, development regions and departure counties, number of persons, 1990-2017, National Institute of Statistics, TempoOnline, P0P309A table - Monthly average net nominal earnings per activity of the national economy at the level of section CANE Rev.1, categories of employees, macroregions, development regions and counties (1990-2008) and CANE-Rev. 2 (2008-2017), in lei (1990-2004) and RON (starting in 2005), National Institute of Statistics, TempoOnline, table F0M106A and F0M106E

- Unemployed registered at the end of the month, by categories of unemployed, sexes, macroregions, development regions and counties, total registered unemployed (indemnified and unpaid), number of persons, National Institute of Statistics, TempoOnline, table S0M101A.

Because the data on immigrants, emigrants and earnings are annual, for registered unemployed we considered the number of unemployed at the end of the year.

The first step in data processing is to verify the stationarity of time series and to identify the integration order if they are not stationary. For this purpose I used the options in Eviews 7.0 software.

We test the nature of the data series. If the time series are non-stationary, then the inclusion in the model implies the appropriate differentiation of the data.

\section{Definitive immigrants}

The stationary tests in the panel for the "Definitive Immigrants" series are presented in the following table:

Table 1. Stationary tests for "Definitive immigrants" for all Romanian counties Group unit root test: Summary

Sample: 1991- 2017

Exogenous variables: Individual effects

Automatic selection of maximum lags

Automatic lag length selection based on SIC: 0 to 5

Newey-West automatic bandwidth selection and Bartlett kernel

\begin{tabular}{|c|c|c|c|c|}
\hline \multicolumn{5}{|l|}{ Series in level } \\
\hline Method & Statistic & Prob.** & Cross-sections & Obs \\
\hline \multicolumn{5}{|c|}{ Null: Unit root (assumes common unit root process) } \\
\hline Levin, Lin \& Chu $t^{*}$ & 4.99264 & 1.0000 & 42 & 1051 \\
\hline \multicolumn{5}{|c|}{ Null: Unit root (assumes individual unit root process) } \\
\hline Im, Pesaran and Shin W-stat & 3.05970 & 0.9989 & 42 & 1051 \\
\hline ADF - Fisher Chi-square & 106.007 & 0.0527 & 42 & 1051 \\
\hline PP - Fisher Chi-square & 82.4368 & 0.5278 & 42 & 1086 \\
\hline
\end{tabular}




\begin{tabular}{|c|c|c|c|c|}
\hline Method & Statistic & Prob.** & Cross-sections & Obs \\
\hline \multicolumn{5}{|c|}{ Null: Unit root (assumes common unit root process) } \\
\hline Levin, Lin \& Chu t* & -24.5722 & 0.0000 & 42 & 1014 \\
\hline \multicolumn{5}{|c|}{ Null: Unit root (assumes individual unit root process) } \\
\hline Im, Pesaran and Shin W-stat & -24.0884 & 0.0000 & 42 & 1014 \\
\hline ADF - Fisher Chi-square & 647.094 & 0.0000 & 42 & 1014 \\
\hline PP - Fisher Chi-square & 762.667 & 0.0000 & 42 & 1041 \\
\hline
\end{tabular}

** Probabilities for Fisher tests are computed using an asymptotic Chi-square distribution. All other tests assume asymptotic normality.

Source: own projection in Eviews 7.0 software

According to the results of the previous table, the time series are non-stationary in level and stationary in the first difference, so we accept that the definitive Immigrant series are I (1), so integrated by the first order.

\section{Definitive emigrants}

The stationary tests in the panel for the "Definitive Emigrants" series are presented in the following table:

Table 2. Stationarity tests for "Definitive emigrants" for all Romanian counties

\begin{tabular}{|l|}
\hline Group unit root test: Summary \\
\hline Sample: 1990 - 2017 \\
\hline Exogenous variables: Individual effects \\
\hline Automatic selection of maximum lags \\
\hline Automatic lag length selection based on SIC: 0 to 5 \\
\hline Newey-West automatic bandwidth selection and Bartlett kernel \\
\hline
\end{tabular}

\begin{tabular}{|c|c|c|c|c|}
\hline Series in level & & & & \\
\hline Method & Statistic & Prob.** $^{* *}$ & $\begin{array}{l}\text { Cross- } \\
\text { sections }\end{array}$ & Obs \\
\hline Null: Unit root (assumes com & unit root $p$ & rocess) & & \\
\hline Levin, Lin \& Chu $\mathrm{t}^{*}$ & -48.9475 & 0.0000 & 42 & 1079 \\
\hline Null: Unit root (assumes indi & al unit root & process) & & \\
\hline Im, Pesaran and Shin W-stat & -40.5057 & 0.0000 & 42 & 1079 \\
\hline ADF - Fisher Chi-square & 817.469 & 0.0000 & 42 & 1079 \\
\hline PP - Fisher Chi-square & 865.791 & 0.0000 & 42 & 1092 \\
\hline
\end{tabular}

** Probabilities for Fisher tests are computed using an asymptotic Chi-square distribution. All other tests assume asymptotic normality.

Source: own projection in Eviews 7.0 software

According to the results of the previous table, the data series are stationary in level, so we accept that the definitive Emigrant series are I (0).

\section{Earnings}

The stationarity tests in the panel for the "Monthly average net nominal nominal earnings" series are presented in the following table: 
Table 3. The stationarity tests for "Monthly net nominal average earning" for all Romanian counties

Group unit root test: Summary

Sample: 1990- 2017

Exogenous variables: Individual effects

Automatic selection of maximum lags

Automatic lag length selection based on SIC: 0 to 5

Newey-West automatic bandwidth selection and Bartlett kernel

\begin{tabular}{|c|c|c|c|c|}
\hline Series in level & & & & \\
\hline Method & Statistic & Prob.** & $\begin{array}{l}\text { Cross- } \\
\text { sections }\end{array}$ & Obs \\
\hline Null: Unit root (assumes com & unit root & ocess) & & \\
\hline Levin, Lin \& Chu t* & 16.4473 & 1.0000 & 42 & 1039 \\
\hline Null: Unit root (assumes indi & al unit root & orocess) & & \\
\hline Im, Pesaran and Shin W-stat & 22.1800 & 1.0000 & 42 & 1039 \\
\hline ADF - Fisher Chi-square & 0.14250 & 1.0000 & 42 & 1039 \\
\hline PP - Fisher Chi-square & 0.03327 & 1.0000 & 42 & 1087 \\
\hline Series in the first differenc & & & & \\
\hline Method & Statistic & Prob.** & $\begin{array}{l}\text { Cross- } \\
\text { sections }\end{array}$ & Obs \\
\hline Null: Unit root (assumes com & unit root & ocess) & & \\
\hline Levin, Lin \& Chu t* & 4.70973 & 1.0000 & 42 & 1040 \\
\hline Null: Unit root (assumes indi & al unit root & orocess) & & \\
\hline Im, Pesaran and Shin W-stat & 1.43225 & 1.0000 & 42 & 1040 \\
\hline ADF - Fisher Chi-square & 57.7411 & 1.0000 & 42 & 1040 \\
\hline PP - Fisher Chi-square & 54.9840 & 1.0000 & 42 & 1045 \\
\hline
\end{tabular}

\section{Double differentiated series}

Method Statistic Prob.** $^{* *} \begin{aligned} & \text { Cross- } \\ & \text { sections }\end{aligned}$ Obs

Null: Unit root (assumes common unit root process)

\begin{tabular}{lllll}
\hline Levin, Lin \& Chu t* & -21.2397 & 0.0000 & 42 & 992
\end{tabular}

Null: Unit root (assumes individual unit root process)

\begin{tabular}{lllll}
\hline Im, Pesaran and Shin W-stat & -22.2959 & 0.0000 & 42 & 992 \\
ADF - Fisher Chi-square & 571.085 & 0.0000 & 42 & 992 \\
PP - Fisher Chi-square & 631.245 & 0.0000 & 42 & 1003 \\
\hline
\end{tabular}

** Probabilities for Fisher tests are computed using an asymptotic Chi-square distribution. All other tests assume asymptotic normality.

Source: own projection in Eviews 7.0 software

According to the results of the previous table, the data series are non-stationary in level and not in the first difference, but become stationary by double differentiation. We accept that the series "Average monthly net nominal earning" are I (2), so integrated by order II. 


\section{Registered unemployed}

The stationarity tests in the panel for the "Registered unemployed" series are presented in the following table:

Table 4. Stationarity tests for "Registered unemployed" for all Romanian counties

\begin{tabular}{|l|}
\hline Group unit root test: Summary \\
\hline Sample: $1990-2017$ \\
\hline Exogenous variables: None \\
\hline Automatic selection of maximum lags \\
\hline Automatic lag length selection based on SIC: 0 to 5 \\
\hline Newey-West automatic bandwidth selection and Bartlett kernel \\
\hline
\end{tabular}

\begin{tabular}{|lclll|}
\hline \multicolumn{1}{l}{ Series in level } & & & \\
\hline \hline Method & Statistic & Prob.** & $\begin{array}{l}\text { Cross- } \\
\text { sections }\end{array}$ & Obs \\
\hline Null: Unit root (assumes common unit root process) & & \\
\hline Levin, Lin \& Chu t* & -8.92693 & 0.0000 & 42 & 1129 \\
& & & \\
\hline & Null: Unit root (assumes individual unit root process) & & \\
\hline ADF - Fisher Chi-square & 168.282 & 0.0000 & 42 & 1129 \\
PP - Fisher Chi-square & 190.315 & 0.0000 & 42 & 1134 \\
\hline
\end{tabular}

** Probabilities for Fisher tests are computed using an asymptotic Chi-square distribution. All other tests assume asymptotic normality.

Source: own projection in Eviews 7.0 software

According to the results from the previous table, the data series are stationary in level. We accept that the "Registered unemployed" series are I (0).

We analyze the hypothesis that the level of immigration is influenced by the unemployment registered at the regional level and by the " The average monthly net nominal earnings ". The model is as follows:

where:

$$
\mathrm{d}\left(\mathrm{IMIGR}_{\mathrm{it}}\right)=\mathrm{a}_{0}+\mathrm{a}_{1} \mathrm{~d}\left(\mathrm{CS}_{\mathrm{it}}, 2\right)+\mathrm{a}_{2} \mathrm{SOM}_{\mathrm{it}}+\beta_{\mathrm{i}}+\delta_{\mathrm{t}}+\mathrm{e}_{\mathrm{it}}
$$

IMIGRit: definitive immigrants in county i, year t;

- $C S_{i t}$ : the average monthly net nominal monthly wage in county $\mathrm{i}$, year $\mathrm{t}$;

- SOMit: unemployed registered in the county i, year t;

- $\mathrm{e}_{\mathrm{it}}$ idiosyncratic error;

- a0, a1, a2: model parameters;

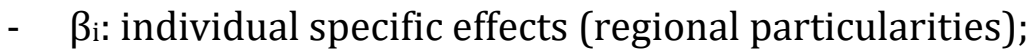

- $\quad \delta_{t}$ : specific effects over time.

We included in the model a scale factor, namely immigration at national level, as well as regional emigration. Also, the estimate showed that the variable CS, "The average monthly net nominal earnings" has a greater significance if it is taken with a delay of a period. Under these conditions, the estimated model is as follows:

$$
\mathrm{d}\left(\text { IMIGR }_{\mathrm{it}}\right)=\mathrm{a}_{0}+\mathrm{a}_{1} \mathrm{~d}\left(\mathrm{CS}_{\mathrm{i}, \mathrm{t}-1,2)}, \mathrm{a}_{2} \mathrm{SOM}_{\mathrm{it}}+\mathrm{a}_{3} \mathrm{EMIGR}_{\mathrm{it}}+\mathrm{a}_{4} \mathrm{~d}\left(\mathrm{IMIGR}_{\mathrm{t}}, 2\right)+\beta_{\mathrm{i}}+\delta_{\mathrm{t}}+\mathrm{e}_{\mathrm{it}} .\right.
$$
where:

EMIGRit: definitive emigrants from county i, year t;

IMIGRt: definitive immigrants, at national level, in year t. The series is I (2). 


\section{Empirical results}

In the model described by the previous equation we checked the significance of individual specific effects $\left(\beta_{i}\right)$. The fixed effects are verified by redundancy tests and the random effects by the Hausman test. For the redundancy test, the tests indicate that specific fixed individual effects are redundant. Consequently, we eliminate the parameters $\beta \mathrm{i}$ from the model. Also, we check for the presence of specific individual random effects through the Hausman test. The probability that the random variables $\beta_{i}$ are correlated with the errors in the model is $20.78 \%$, a value higher than the standard threshold of $5 \%$. Consequently, we eliminate the individual specific effects (fixed, or random) from the model specification.

Table 5. Hausman test for specific individual random effects

Correlated Random Effects - Hausman Test

Pool: POOL01

Test cross-section random effects

\begin{tabular}{lllll}
\hline \hline Test Summary & & $\begin{array}{l}\text { Chi-Sq. } \\
\text { Statistic }\end{array}$ & Chi-Sq. d.f. & Prob. \\
\hline \hline Cross-section random & & 5.886794 & 4 & 0.2078 \\
\hline \hline \multicolumn{2}{l}{ Cross-section random effects test comparisons: } & & \\
Variable & Fixed & Random & Var(Diff.) & Prob. \\
\hline \hline D(CS?(-1),2) & 0.564966 & 0.611952 & 0.001422 & 0.2128 \\
SOM? & -0.004622 & -0.000479 & 0.000006 & 0.0779 \\
EMIGR? & 0.240862 & 0.173804 & 0.004816 & 0.3339 \\
D(IMIGR_TOTAL,2) & 0.013506 & 0.014391 & 0.000000 & 0.0245 \\
\hline \hline
\end{tabular}

Source: own projection in Eviews 7.0 software

If we include specific effects in the model in fixed time, the model cannot be specified. For specific random effects over time $\left(\delta_{t}\right)$, the Hausman test looks like the probability that the random variables $\delta$ t are correlated with the errors in the model is $39.78 \%$, a value higher than the standard threshold of 5\%. Consequently, we eliminate the specific effects in time (fixed, or random) from the model specification.

\section{Model estimation}

Considering the previous results, regarding the specific effects (individual, or in time, respectively, fixed, or random), the model analyzed is:

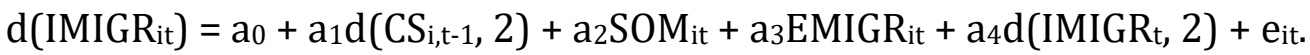

The estimation results are as follows:

Dependent Variable: d(IMIGR?)

Table 6. Panel model for "Definitive Immigrants" at regional level

Method: Pooled EGLS (Period SUR)

Sample (adjusted): 1999- 2017

Included observations: 19 after adjustments

Cross-sections included: 42

Total pool (balanced) observations: 798

Linear estimation after one-step weighting matrix 


\begin{tabular}{lllll}
\hline \hline Variable & Coefficient & Std. Error & t-Statistic & Prob. \\
\hline \hline C & -12.26099 & 2.462002 & -4.980090 & 0.0000 \\
d(CS?(-1),2) & 0.331368 & 0.033413 & 9.917434 & 0.0000 \\
SOM? & -0.000458 & 0.000198 & -2.318760 & 0.0207 \\
EMIGR? & 0.170502 & 0.004031 & 42.29847 & 0.0000 \\
d(IMIGR_TOTAL,2) & 0.007484 & 0.000943 & 7.938663 & 0.0000 \\
\hline \hline \multicolumn{4}{l}{ Weighted Statistics } & \\
\hline \hline R-squared & 0.742709 & Mean dependent var & 0.081860 \\
Adjusted R-squared & 0.741411 & S.D. dependent var & 2.097910 \\
S.E. of regression & 0.953653 & Sum squared resid & 721.1970 \\
F-statistic & 572.2786 & Durbin-Watson stat & 1.925252 \\
Prob(F-statistic) & 0.000000 & & \\
\hline \hline & Unweighted Statistics & \\
\hline R-squared & 0.065270 & Mean dependent var & 47.98496 \\
Sum squared resid & $2.81 E+08$ & Durbin-Watson stat & 1.643250 \\
\hline \hline
\end{tabular}

Source: own projection in Eviews 7.0 software

\section{Conclusion}

For estimation, we used the SUR (seemingly unrelated regression) option for the period. The SUR Period option allows efficient estimators to be obtained under the general correlation of residuals over periods for a given cross-section (individual grouping). (Jula \& Jula, Time series econometrics, 2019).

The model is significant as a whole (the probability of non-zero coefficients is Prob (Fstatistic) $<0.0001$ ) and explains $74.17 \%$ of the variation compared to the average number of immigrants. The estimators are significantly different from zero, at the $1 \%$ threshold.

The estimator of the coefficient $\mathrm{a}_{1}$ [attached to the variable $\mathrm{d}(\mathrm{CSi}, \mathrm{t}-1,2)$ ] is positive and significantly different from zero. This means that higher earning areas attract immigrants.

The link between unemployment and immigration is negative ( $\left.\hat{a}_{2}=-0.000458\right)$ and significantly different from zero.

Also, immigration and emigration are positively correlated, and the national dynamics of immigration set the regional dimensions of the phenomenon.

\section{References}

Anghel, R. G., Istavn H.: Sociology of migration. Romanian theories and case studies, Polirom Publishing House (2009)

Ciocănescu, E. A .: External migration: from the country of origin Romania, to the countries of destination in the European Union area - a brief analysis for the years 1998 - 2009, Statistical Magazine of Romania, no. 7/2011, (2011), accessed at [http://www.revistadestatistica.ro/wpcontent/uploads/2014/02/RRS_7_2011_A6_en.pdf]

Feraru, P. D .: Migration and development: socio-economic aspects and trends, Lumen Publishing House (2011)

International Organization for Migration (IOM): World Migration 2003 - Managing Migration: Challenges and Responses for People on the Move, Geneva (2003)

Jula, D., Jula, N. M.: Econometrics of time series., Mustang Publishing House, Bucharest (2019)

Jula, D., Jula, N. M.: Econometrics, Mustang Publishing House, Bucharest (2019)

National Institute of Statistics: International Migration of Romania (2014)

Newell, C.: Methods and Models in Demography - Belhaven Press, London (1988) 
Roman, M., Voicu, C.: Some socio-economic effects of labor migration on the countries of emigration. The case of Romania., Theoretical and applied economics, Volume XVII, Nr. 7 (548), pp. 50-65, Romania (2010)

Roman, M., Zizi G., Roman, M., Popa, A., Ileanu, B. V.: The Romanian emigration. Economic and demographic implications, ASE Publishing House (2012)

Sandu, D., Radu, C., Constantinescu, M., Ciobanu, O.: A country report on romanian migration aboard: stocks and flows after 1989, (2004) study for www.migrationonline.cz

Sandu, D.: Temporary residence abroad. The economic migration of Romanians 1990 2006, Polirom Publishing House, Iași (2007)

Stănculescu, M., Stoiciu, V., Alexe, I., Moțoc, L .: The impact of the economic crisis on the migration of the Romanian labor force, Friedrich Ebert Stiftung, Bucharest (2011) accessed at http://www.fes.ro/ media / images / publications / Impactul_crizei.pdf

Stoica, I.: The Temptation of Migration. Necessity and opportunity in a globalized world, Military Publishing House (2011)

Trewartha, G. T.: A Geography of Population: World Pattern, John Wiley \& Sons, Inc., New York (1969)

Voineagu, V., Țițan, E., Ghiță, S., Boboc, C., Todose, D.: Statistics. Theoretical bases and applications, Economic Publishing House (2007)

Zelinsky, W.: A Prologue to Population Geography, Prentice Hall, Englewood Cliffs, New Jersey (1966)

[http://ro.scribd.com/doc/8042281/Migratia-Fortei-de-Munca]

[http://en.wikipedia.org/wiki/Human_migration]

[http://statistici.insse.ro]

[http://data.worldbank.org]

[http://epp.eurostat.ec.europa.eu/portal/page/portal/statistics/search_database]

DEX- [https://dexonline.ro/definitie/migra\%C8\%9Bie] 